\title{
Serum Levels of Hyaluronic Acid (HA) and Cartilage Oligomeric Matrix Protein (COMP). Predictors of Disease Progression in Rheumatoid Arthritis
}

\author{
*Manal A. Safan, ${ }^{*}$ Maathir K. El Shafie and ${ }^{* *}$ Samer G. Soliman \\ *Medical Biochemistry, ${ }^{* *}$ Rheumatology Departments, Faculty of \\ Medicine, Minoufia University
}

\begin{abstract}
Rheumatoid arthritis (RA) is a disease characterized by destruction of joint structures such as articular cartilage and bone. The pathogenic mechanisms responsible for tissue destruction are not well understood. The aim of the present study was to measure the serum concentrations of specific cartilage and bone molecules reflecting tissue turnover to investigate disease activity. The study included 30 rheumatoid arthritis (RA) patients with age range 42 - 66 years, sixteen patients were rapid erosive patients and fourteen were slow erosive, compared with 20 matched normal population with age range $40-63$ years. All studied individuals were subjected to full history taking clinical examination and laboratory investigations including measurement of serum levels of cartilage oligomeric matrix protein (COMP), hyaluronic acid (HA), high sensitive C- reactive protein (CRP), erythrocyte sedimentation rate (ESR) and RF concentration, measurement of activity of RA by disease activity score (DAS) 28 joint counts. The study showed a significantly higher values of COMP, HA, CRP and ESR in slow erosive $(P<0.001)$ and rapid erosive $(P$ $<0.0001) R A$ patients when compared to controls. There were significantly higher values of COMP, HA, CRP and ESR in rapid erosive RA patients compared to slow erosive RA patients. A significant positive correlation between serum levels of COMP and HA and age, disease duration, Larsen score, DAS and CRP and ESR was found. Also, there was a significant positive correlation between serum levels of COMP and HA $(r=0.674, P<0.01)$. It could be concluded that the measurement of some serological biomarkers that reflect bone and cartilage destruction in $R A$ patients, could be used to investigate disease activity and increase the knowledge of the basic pathophysiology of joint disease.
\end{abstract}

\section{INTRODUCTION}

Arthritis is a longstanding, debilitating disease that results in serious sequle on the population. It causes pain, impairment, and disability in patients with increasing injury to the cartilage, synovium and bone of the affected joints ${ }^{(1)}$.
Existing methods to diagnose and to monitor the disease are based on late clinical manifestations of arthritis. However, with recent development of successful treatments for rheumatoid arthritis and osteoarthritis, it becomes important to identify prognostic factors that can predict the evolution of arthritis. This would be of most 
value in the early phases of the disease so that treatments could be started rapidly to help slow down progression of the disease ${ }^{(\mathbf{1}) \text {. }}$

A possible approach to monitor arthritis is the measurement of biological markers of cartilage repair and degradation to reflect variations in joint remodeling. One such potential biological marker of arthritis is cartilage oligomeric matrix protein $(\mathrm{COMP})^{(2)}$.

COMP is also known as thrombospondin 5. It is a $524 \mathrm{kDa}$ homopentameric extracellular matrix glycoprotein member of the thrombospondin family of calciumbinding proteins with five identical subunits ${ }^{(3 \& 4)}$.

The function of COMP remains unclear, but it may have a structural role in endochondral ossification and in the assembly and stabilization of the extracellular matrix by its interaction with collagen fibrils and matrix components ${ }^{(\mathbf{5 \& 6})}$.

COMP was first detected in the serum and the synovial fluid of patients suffering from rheumatoid disorders, such as RA, reactive arthritis, juvenile chronic arthritis, and osteoarthritis $\quad(\mathrm{OA})^{(7)}$. Serum concentrations of COMP are initially elevated in patients with early RA who later develop extensive joint destruction. This suggested that disease pathogenesis is characterized by abnormal turnover of that protein in these patients ${ }^{(8)}$.

Hyaluronic acid (HA), is a glycosaminoglycan formed from alternating units of $\mathrm{N}$ - acetyl glucosamine and glucuronic acid ${ }^{(\mathbf{9})}$. It is a constituent of synovium and cartilage and is thought to contribute to the lubricating mechanisms of synovial fluid. Local increased production of HA has been demonstrated in inflamed synovium from patients with RA, osteoarthritis (OA), ankylosing spondylitis, and reactive arthritis ${ }^{(10)}$.

Serum levels of HA have been shown to be increased in individuals with liver disease ${ }^{(11)}$, cancer ${ }^{(\mathbf{1 2})}$, hypothyroidism $^{(\mathbf{1 3})}$, amyloidassociated arthropathy ${ }^{(14)}, \mathrm{OA}^{(15)}$, and psoriasis with or without arthropathy $^{(\mathbf{1 6})}$.

The aim of the present study was to measure the serum concentrations of specific cartilage and bone molecules reflecting tissue turnover to investigate disease activity.

\section{SUBJECTS \& METHODS}

The study included 50 subjects; they were classified into 2 main groups: Group A:

It included 30 rheumatoid arthritis patients, who all fulfilled the American College of Rheumatology (formerly, the American Rheumatism Association) 1987 Criteria for RA ${ }^{(17)}$, with age range 42-66 years, it included 18 females and 12 males. The median disease duration is 1.4 years (range 0.2-2.7 years), disease onset was defined as the time of onset of joint symptoms according to history at the initial visit to the department. It is subdivided into 2 subgroups according to radiographic examination using the Larsen method according to Petterson ${ }^{(18)}$

\section{Group IA:}

It included sixteen patients who developed significant erosive disease 
of the knee joints (rapid erosive group)

\section{Group IIA:}

It included fourteen patients without rapidly progressive disease (slow erosive group).

\section{Group B (control group):}

It included 20 age and sex matched healthy volunteers. It included 11 females and 9 males with age range $40-63$ years.

All patients were attendants of the Rheumatology Department of Minoufia University Hospital in the period from February 2008 to May 2009.

Patients with liver diseases, hypothyroidism, chronic renal diseases, $\mathrm{OA}$ and psoriasis were excluded from the study.

The following measures were recorded for RA patients: number of swollen joints, number of tender joints, patient's assessment of pain on a visual analogue scale (VAS) and patient's assessment of disease activity on a VAS. Disease activity score (DAS) were calculated with assessment of swollen and tender joints using 28-joint counts ${ }^{(19)}$.

Radiographic examination:

Hands, wrists and feet of the 30 RA patients were examined radiographically. The radiographs were graded by the same radiologist without knowledge of clinical data using the Larsen method modified according to Pettersson ${ }^{(18 \& 20)}$. That method is based on comparisons with standard radiographs, where 0 denotes a radiographically normal joint and 5 denotes the one with maximum degree of joint destruction. A theoretical range of values from 0 to 200 were used to grade these joints.
All patients and controls were subjected to full history taking, clinical examination and laboratory investigations including measurement of serum levels of COMP, HA, ultrasensitive $\mathrm{C}$ - reactive protein (CRP), erythrocyte sedimentation rate (ESR) and determination of rheumatoid factor titer.

\section{Sample collection and assay:}

$5 \mathrm{ml}$ of venous blood were collected from all fasting subjects into a plain tube, let to stand to clot and serum was separated in aliquots after centrifugation and stored at $-70^{\circ}$ until analysis of the following parameters: HA using an enzyme-linked binding protein assay that uses a capture molecule known as hyaluronic acid binding protein (HABP) ${ }^{\text {(21) }}$. Serum COMP levels was measured by enzyme-linked immunosorbent assay (ELISA) ${ }^{(22)}$.

Erythrocyte sedimentation rate (ESR) was determined according to Westergreen method and ultrasensitive CRP assay by using latex enhanced immunoturbidimetric assay. Serum CRP causes agglutination of the latex particles coated antihuman CRP, the agglutination of the latex particles is proportional to CRP concentration ${ }^{(23)}$. Rheumatoid factor titer was determined using RF-latex which is a slide agglutination test for the qualitative and semiquantitative detection of RF in human serum. Latex particles coated with human gamma globulin are agglutinated when mixed with samples containing $\mathrm{RF}^{(24)}$.

\section{Statistical analysis:}

The data were statistically analyzed by SPSS 14 software 
package. Differences between groups were calculated using MannWhitney's test for unpaired variables. Differences between three groups were compared by means of ANOVA test. Correlations between variables were calculated by spearman's correlation coefficient. $\mathrm{P}$ values $<0.05$ were considered significant. Assessment of optimal cut off points was done by using receiver operating characteristic (ROC) curve analysis ${ }^{(25)}$.

\section{RESULTS}

Table (1): Serum levels of HA, COMP, CRP and ESR in RA patients ( group A) and controls( group B)

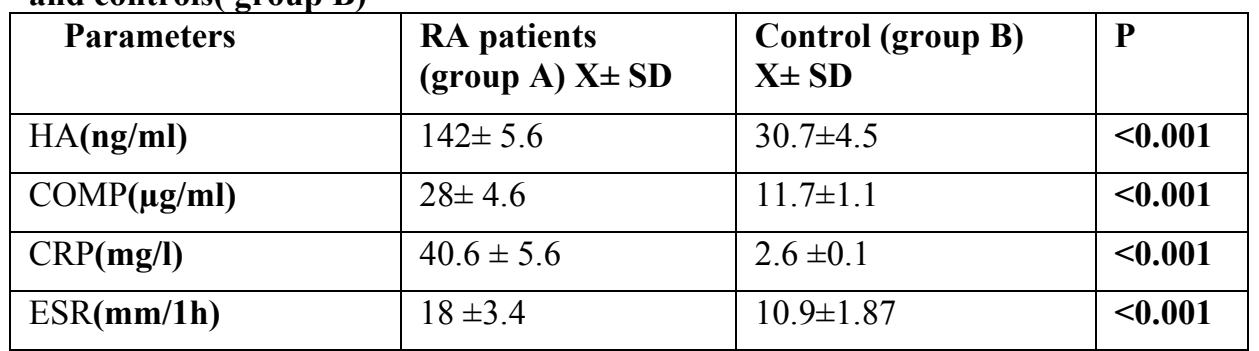

hyaluronic acid (HA), cartilage oligomeric matrix protein (COMP), erythrocyte sedimentation rate (ESR), ultrasensitive CRP.

There are significantly higher values of HA, COMP, CRP and ESR in RA patients when compared to controls.

Table (2): Characteristics of patients

\begin{tabular}{|c|c|c|c|}
\hline & $\begin{array}{l}\text { Slow erosive } \\
\text { group } \\
\text { Group11A } \\
\text { X } \pm \text { SD }\end{array}$ & $\begin{array}{l}\text { Rapid erosive } \\
\text { group } \\
\text { Group 1A } \\
\text { X } \pm \text { SD }\end{array}$ & $\mathbf{P}$ \\
\hline $\begin{array}{l}\text { Number of patients (female/ } \\
\text { male) }\end{array}$ & $14(8 / 6)$ & $16(10 / 6)$ & $>0.05^{*}$ \\
\hline Age at disease onset (years) & $59 \pm 5.6$ & $47 \pm 6.7$ & $<0.001$ \\
\hline Duration of disease (years) & $2.9 \pm 0.96$ & $2.3 \pm 0.75$ & $>0.05$ \\
\hline RF positivity no. (\%) & $9(64.3 \%)$ & $12(75 \%)$ & $>0.05^{*}$ \\
\hline $\begin{array}{l}\text { Radiographic index (Larsen } \\
\text { score: } 0-200) \text { ) }\end{array}$ & $6.9 \pm 1.7$ & $30.8 \pm 3.6$ & $<0.001$ \\
\hline disease activity score (DAS) (0-10) & $3 \pm 0.2$ & $3.2 \pm 0.5$ & $>0.05$ \\
\hline
\end{tabular}

* by Chi square test

There are no significant differences in the number of patients, gender, duration of RA disease, DAS and RF status. However, there is a significant difference as 
regarding the age of the patients, also the patients who had rapid erosion have a significant higher Larsen score than those with slow erosion.

Table (3): Serum levels of HA, COMP, CRP and ESR in the slow erosive RA patients and controls.

\begin{tabular}{|l|l|l|l|}
\hline & $\begin{array}{l}\text { Control group } \\
(\mathbf{n = 2 0}) \\
\mathbf{X} \pm \mathbf{S D}\end{array}$ & $\begin{array}{l}\text { Slow erosive group } \\
(\mathbf{n = 1 4 )} \\
\mathbf{X} \pm \mathbf{S D}\end{array}$ & $\mathbf{P}$ \\
\hline HA $(\mathbf{n g} / \mathbf{m l})$ & $30.7 \pm 4.5$ & $45.3 \pm 5.6$ & $<\mathbf{0 . 0 0 1}$ \\
\hline COMP $(\boldsymbol{\mu g} / \mathbf{m l})$ & $11.7 \pm 1.1$ & $16.83 \pm 1.5$ & $<\mathbf{0 . 0 0 1}$ \\
\hline CRP $(\mathbf{m g} / \mathbf{l})$ & $2.6 \pm 0.1$ & $8.5 \pm \mathbf{0 . 3}$ & $<\mathbf{0 . 0 0 1}$ \\
\hline ESR $(\mathbf{m m} / \mathbf{1 h})$ & $10.9 \pm \mathbf{1 . 8 7}$ & $20.41 \pm \mathbf{2 . 1 8}$ & $<\mathbf{0 . 0 0 1}$ \\
\hline
\end{tabular}

There are significantly higher values of HA, COMP, CRP and ESR in slow erosive RA patients compared to controls.

Table (4): Serum levels of HA, COMP, CRP and ESR in the rapid erosive RA patients and controls.

\begin{tabular}{|l|l|l|l|}
\hline & $\begin{array}{l}\text { Control group }(\mathbf{n}=\mathbf{2 0}) \\
\mathbf{X} \pm \text { SD }\end{array}$ & $\begin{array}{l}\text { Rapid erosive group } \\
(\mathbf{n = 1 6}) \\
\mathbf{X} \pm \text { SD }\end{array}$ & $\mathbf{P}$ \\
\hline HA $(\mathbf{n g} / \mathbf{m l})$ & $30.7 \pm 4.5$ & $175.7 \pm 25.2$ & $<\mathbf{0 . 0 0 0 1}$ \\
\hline COMP $(\boldsymbol{\mu g} / \mathbf{m l})$ & $11.7 \pm 1.1$ & $32.8 \pm 3.1$ & $<\mathbf{0 . 0 0 0 1}$ \\
\hline CRP $(\mathbf{m g} / \mathbf{l})$ & $2.6 \pm 0.1$ & $58 \pm 6.2$ & $<\mathbf{0 . 0 0 0 1}$ \\
\hline ESR $(\mathbf{m m} / \mathbf{1 h})$ & $10.9 \pm \mathbf{1 . 8 7}$ & $52 \pm \mathbf{4 . 1}$ & $<\mathbf{0 . 0 0 0 1}$ \\
\hline
\end{tabular}

There are significantly higher values of HA, COMP, CRP and ESR in rapid erosive RA patients compared to controls.

Table (5): Serum levels of HA, COMP, CRP and ESR in the rapid erosive and slow erosive RA patients group.

\begin{tabular}{|l|l|l|l|}
\hline & $\begin{array}{l}\text { Slow erosive group } \\
(\mathbf{n}=\mathbf{1 4}) \\
\text { X } \pm \text { SD }\end{array}$ & $\begin{array}{l}\text { Rapid erosive group } \\
(\mathbf{n}=\mathbf{1 6}) \\
\text { X } \pm \text { SD }\end{array}$ & P \\
\hline HA $(\mathbf{n g} / \mathbf{m l})$ & $45.3 \pm 5.6$ & $175.7 \pm 25.2$ & $<\mathbf{0 . 0 1}$ \\
\hline COMP $(\boldsymbol{\mu g} / \mathbf{m l})$ & $16.83 \pm 1.5$ & $32.8 \pm 3.1$ & $<\mathbf{0 . 0 0 0 1}$ \\
\hline CRP $(\mathbf{m g} / \mathbf{l})$ & $8.5 \pm \mathbf{0 . 3}$. & $58 \pm 6.2$ & $<\mathbf{0 . 0 0 1}$ \\
\hline ESR $(\mathbf{m m} / \mathbf{1 h})$ & $20.41 \pm \mathbf{2 . 1 8}$ & $52 \pm \mathbf{4 . 1}$ & $<\mathbf{0 . 0 0 1}$ \\
\hline
\end{tabular}

There are significantly higher values of HA, COMP, CRP and ESR in rapid erosive compared to slow erosive RA patients 
Table (6): Relationship between serum levels of COMP and HA and diseaserelated characteristics.

\begin{tabular}{|c|c|c|c|c|}
\hline & \multicolumn{2}{|l|}{ HA( $\mathrm{ng} / \mathrm{ml})$} & \multicolumn{2}{|c|}{$\operatorname{COMP}(\mu \mathrm{g} / \mathrm{ml})$} \\
\hline & $\mathbf{X} \pm \mathrm{SD}$ & $\mathbf{P}$ & $\mathbf{X} \pm \mathbf{S D}$ & $\mathbf{P}$ \\
\hline $\begin{array}{l}\text { Duration of disease: } \\
\text { - less than } 2 \text { years } \\
\text { - more than } 2 \text { years }\end{array}$ & $\begin{array}{l}43 \pm \mathbf{4 . 1} \\
145 \pm 12.1\end{array}$ & $<0.001$ & $\begin{array}{l}15 \pm \mathbf{1 . 1} \\
25.6 \pm 2.2\end{array}$ & $<0.001$ \\
\hline $\begin{array}{l}\text { Larsen score: } \\
\text { - least erosive disease } \\
\text { - more erosive disease }\end{array}$ & $\begin{array}{l}52.3 \pm \mathbf{6 . 1} \\
163.6 \pm \mathbf{2 0 . 3}\end{array}$ & $<0.001$ & $\begin{array}{l}16.3 \pm 2.1 \\
27.6 \pm 2.3\end{array}$ & $<0.001$ \\
\hline $\begin{array}{l}\text { DAS: } \\
\text { - mild } \\
\text { - moderate } \\
\text { - high }\end{array}$ & $\begin{array}{l}15.6 \pm 0.3 \\
36.4 \pm 1.9 \\
156.7 \pm \mathbf{1 2 . 3}\end{array}$ & $\begin{array}{l}\text { F value } \\
(21.4) \\
<0.001 *\end{array}$ & $\begin{array}{l}12.8 \pm \mathbf{1 . 2} \\
20.4 \pm 2.1 \\
30.3 \pm 3.4\end{array}$ & $\begin{array}{l}\text { F value } \\
(9.3) \\
<0.01^{*}\end{array}$ \\
\hline $\begin{array}{l}\text { RF status: } \\
\text { - RF seropositive } \\
\text { - RF seronegative }\end{array}$ & $\begin{array}{l}57.3 \pm \mathbf{8 . 8} \\
52.7 \pm 7.9\end{array}$ & $>0.05$ & $\begin{array}{l}18.5 \pm 4.7 \\
16.3 \pm 4.1 \\
\end{array}$ & $>0.05$ \\
\hline
\end{tabular}

* By ANOVA test, disease activity score (DAS), rheumatoid factor ( RF)

There are significantly higher values of COMP and HA in RA patients with disease duration more than 2 years, in more erosive Larsen patients group and in high more than moderate and mild DAS. However, There are no significant differences in the serum levels of COMP and HA in RF seropositive and RF seronegative patient groups.

Table (7): Correlations between serum concentration of COMP, HA and patient characters, CRP and ESR.

\begin{tabular}{|l|l|l|l|l|}
\hline & \multicolumn{2}{|l|}{ HA $(\mathbf{n g} / \mathbf{m l})$} & \multicolumn{2}{l|}{ COMP $(\boldsymbol{\mu g} / \mathbf{m l})$} \\
\hline & $\mathrm{r}$ & $\mathrm{P}$ & $\mathrm{R}$ & $\mathrm{P}$ \\
\hline Age of patients (years) & 0.524 & $<0.05$ & 0.542 & $<0.05$ \\
\hline Disease duration (years) & 0.546 & $<0.05$ & 0.283 & $<0.01$ \\
\hline Larsen score & 0.526 & $<0.05$ & 0.591 & $<0.01$ \\
\hline DAS & 0.627 & $<0.01$ & 0.563 & $<0.01$ \\
\hline CRP (mg/l) & 0.537 & $<0.05$ & 0.272 & $<0.01$ \\
\hline ESR (mm/1h) & 0.614 & $<0.01$ & 0.524 & $<0.05$ \\
\hline
\end{tabular}

There are significant positive correlations between serum levels of COMP and HA with age, disease duration, Larsen score, DAS, CRP and ESR. 
Table (8): Correlation between serum concentrations of COMP and HA in the patients group.

\begin{tabular}{|l|l|l|}
\hline HA (ng/ml) & R & P \\
\hline COMP $(\boldsymbol{\mu g} / \mathbf{m l})$ & 0.674 & $<0.01$ \\
\hline
\end{tabular}

correlation coefficient $(r)$

There is significant positive correlation between serum levels of COMP and HA.

Table (9): Cutoff values, specificity and sensitivity of COMP and HA in RA patients.

\begin{tabular}{|l|l|l|}
\hline & COMP $(\boldsymbol{\mu g} / \mathbf{m l})$ & HA(ng/ml $)$ \\
\hline Cutoff & 15.17 & 60 \\
\hline Sensitivity & $72.6 \%$ & $42.6 \%$ \\
\hline Specificity & $79 \%$ & $71.1 \%$ \\
\hline
\end{tabular}

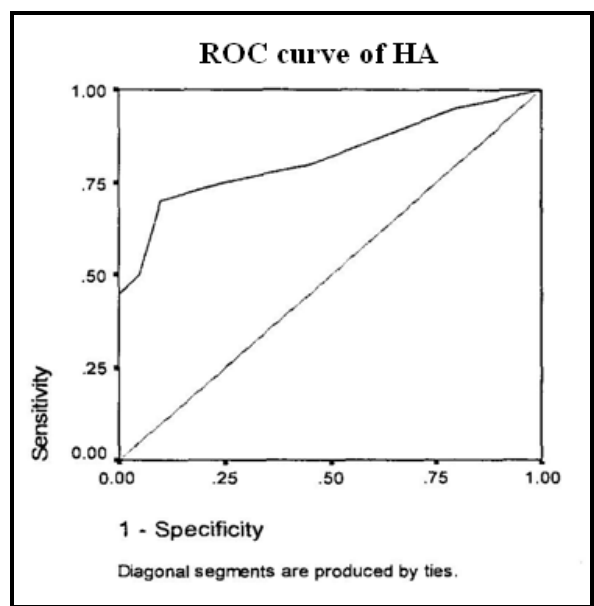

\section{DISCUSSION}

Rheumatoid arthritis (RA) is a disease characterized by destruction of joint structures such as articular cartilage and bone ${ }^{(2)}$. The pathogenic mechanisms responsible for tissue destruction are not well understood ${ }^{(\mathbf{2 6})}$. Furthermore, it is not clear why joint destruction progresses very slowly in

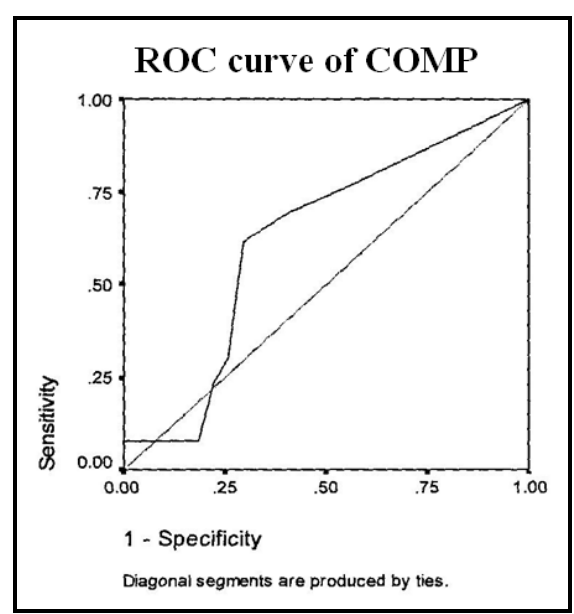

some patients and causes little tissue derangement, whereas in others extensive destruction occurs within a few years after disease onset ${ }^{\text {(27\&2) }}$

The use of immunoassays for the quantification of cartilage and bone molecules which enter the circulation as part of tissue turnover that occur in $\mathrm{RA}$, has reflected the changes in the metabolism of extracellular matrix in these tissues ${ }^{(27)}$. 
The present study demonstrated that there are no significant differences in the number of patients, gender, duration of RA, DAS and RF status in the rapid erosive and the slow erosive patient groups. However, there is a significant difference as regard the age of the patients, also the patients who had rapid erosion have a significant higher Larsen score than those with slow erosion.

Majeed et al. and Young et al. ${ }^{(}$ 28\&29), have reported that there were no significant differences in gender, age of patients, disease duration, RF positivity and DAS. However, the patients with radiographic progression had a higher Larsen score.

The present study demonstrated a significant increase in serum levels of HA in RA patients compared with control group, using cut off point of $60 \mathrm{ng} / \mathrm{ml}$, test sensitivity was $42.6 \%$ and specificity was $71.1 \%$. The levels of HA were higher in the rapid erosive group than in the slow erosive group, these results agreed with those of Santos et al. and Majeed et al. ${ }^{(30 \& 28)}$ who suggested that an increased systemic level might act as an early indicator of structural damage and hence provide a useful prognostic marker.

Elliott et al. ${ }^{(15)}$ have reported that HA is produced locally by cells of the ECM, degradation and turnover of the ECM result in release of HA and HA fragments into the systemic circulation. Increased production and release of HA from arthritis joints are thought to reflect the localized inflammation of synovial lining and, to a lesser extent, to cartilage degradation.
Chubinskaya et al. (30) have postulated that levels of HA were higher in RA patients than in asymptomatic donors. These results, also, go with those of Pothacharoen et al. ${ }^{(32)}$ who suggested that RA may be detected systemically according to these results.

In the current study, RA patients showed a significant increase of COMP compared with the control group, using a cut off value of 15.17 $\mu \mathrm{g} / \mathrm{ml}$, test sensitivity was $72.6 \%$ and specificity was $79 \%$.

The levels of COMP were higher in the rapid erosive group than in the slow erosive group, these results agreed with those of Poole et al. and Bengt et al. (33\&27)

Galeotti et al. ${ }^{(34)}$ have reported that there is a significant increase in COMP serum levels in adult RA compared to age- and gender-matched controls having no inflammatory disease.

Morozzi et al. ${ }^{(7)}$ demonstrated that increased levels of COMP in RA could be used as a potential marker for measuring articular cartilage damage. These results were similar to those reported by Skoumal et al. and Posey and Hecht ${ }^{(35 \& 6)}$, who found that increased serum levels of COMP in RA patients reflect increased cartilage turnover.

Also, Syversen et al. $^{(2)}$ have reported that COMP and other cartilage and bone biomarkers will serve as more useful prognostic markers than current predictors such as anti-cyclic citrullinated peptide (ACCP), radiographic damage early in the disease course, and signs of inflammation. 
The present study demonstrated a significant increase in serum levels of CRP and ESR in RA patients compared with control group. The levels of CRP and ESR were higher in the rapid erosive group than in the slow erosive group, these results agreed with those of Bengt et al. and Majeed et al. ${ }^{(27 \& 28)}$

In the current study, significant positive correlations between serum levels of HA and age of the patients at disease onset, disease duration, DAS and Larsen score were detected, in accordance to results reported by Emlen et al. ${ }^{(36)}$

In the current study, a significant positive correlation was detected between serum levels of HA and ESR and CRP as recorded by Bengt et

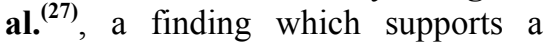
connection between joint and systemic inflammation.

Majeed et al. ${ }^{(28)}$ demonstrated that HA serum levels are correlated with measures of disease activity including swollen joint count, tender joint count and pain VAS. However, there is a strong positive correlation with laboratory indices of disease activity (ESR and CRP) rather than with the clinical indices of the disease.

In the current study, significant positive correlations between serum levels of COMP and age of the patients at disease onset, disease duration, DAS and Larsen score were detected. These results agreed with those of Wislowska and Jablonska, (37) who reported that serum COMP levels were correlated to the age of RA patients and DAS value.

Marti et al. ${ }^{(38)}$ have reported that a high clinical disease activity (DAS) was correlated with high COMP values in serum and synovial fluid and with increasing proteolytic activity. An increased turnover of cartilage matrix in joint inflammation might explain that correlation.

These results agreed also with those of Skoumal et al. and De Jong et al. ${ }^{(35 \& 39)}$ who found positive correlations between serum levels of COMP and Larsen score and DAS. These results, also, paralleled those of Lindqvist et al. ${ }^{(40)}$ who reported that serum levels of COMP were significantly elevated in patients whose RA progressed radiographically compared with those whose disease remained radiographically stable, and levels correlated with radiographic progression.

In the current study, significant positive correlations between COMP and ESR and CRP were detected. These results, also, go with those of Momohara et al.; Soderlin et al. and Fujikawa et al. ${ }^{(41,42 \& 43)}$ who reported that serum COMP levels correlated with ESR and CRP, which are indicators of the acute-phase response, these findings suggest that serum COMP levels may reflect cartilage destruction..

In the current study, There are significantly higher values of COMP and HA in RA patients with disease duration more than 2 years, in more erosive Larsen group patients and in high more than moderate and mild DAS. However, there are no significant differences in the serum levels of COMP and HA in RF seropositive and RF seronegative patient groups.

Momohara et al. ${ }^{(41)}$ have postulated that COMP serum levels of 
the patients with least erosive disease (LES) group were significantly lower than those of the patients with more erosive disease (MES) group. YoungMin et al. ${ }^{(29)}$ have reported that increased COMP serum levels in RA patients are correlated significantly with radiographic progression of the disease, which indicate that COMP is a useful predictor of radiographic progression in RA.

Majeed et al. ${ }^{(28)}$ found that no significant difference was found in HA serum levels between RF seropositive and RF seronegative patients.

A significant positive correlation between serum levels of HA and COMP was found in the present study, a similar result was reported by Bengt et al. ${ }^{(27)}$

Serum COMP was found to be a specific marker for the cartilage degradation in RA and not related to the nonspecific inflammatory process, as there was a significant difference in levels when compared to patients with other inflammatory rheumatic diseases with less cartilage-destructive arthritis ${ }^{(44) \text {. }}$

Consequently, it could be concluded that the measurement of some serological biomarkers that reflect bone and cartilage destruction in RA patients (COMP and HA) could be used to investigate disease activity and increase the knowledge of the basic pathophysiology of joint disease. These observations draw attention to the fact that the measurement of cartilage derived macromolecules could be used for prognostic purposes and in therapeutic studies.

\section{REFERENCES}

1. Tseng S, Reddi AH and Di Cesare PE (2009): Cartilage oligomeric matrix protein (COMP): A biomarker of arthritis. Biomarke Insights 17 (4): 33-44.

2. Syversen SW, Goll GL, van der Heijde D, Landewé R, Gaarder PI, Odegård S, Haavardsholm EA and Kvien TK (2009): Cartilage and Bone Biomarkers in Rheumatoid Arthritis: Prediction of 10-year Radiographic Progression. J. Rheumatol., 36 (2): 266-72.

3. Hedbom E, Antonsson $P$, Hjerpe A, et al. (1992): Cartilage matrix proteins. An acidic oligomeric protein (COMP) detect only in cartilage. J. Biol. Chem., 267: 6132-6.

4. Bjornhart B, Juul A, Nielsen S, Zak $M$, Svenningsen $P$ and Müller K (2009): Cartilage oligomeric matrix protein in patients with juvenile idiopathic arthritis: relation to growth and disease activity. J. Rheumatol., 36 (8): 1749-54.

5. Halasz K, Kassner A, Morgelin $M$ and Heinegard $D$ (2007): COMP acts as a catalyst in collagen fibrillogenesis. J. Biol. Chem., 282: 31166-73.

6. Posey KL and Hecht JT (2008): The role of cartilage oligomeric matrix protein (COMP) in skeletal disease. Curr. Drug Targets., 9 (10): 869-77.

7. Morozzi G, Fabbroni M, Bellisai F, Pucci $G$ and Galeazzi M (2007): Cartilage oligomeric matrix protein level in 
rheumatic diseases: potential use as a marker for measuring articular cartilage damage and/or the therapeutic efficacy of treatments. Ann. N Y Acad. Sci., 1108: 398-407.

8. Nikolaisen C, Rekvig OP and Nossent HC (2007): Diagnostic impact of contemporary biomarker assays for rheumatoid arthritis. Scand. J. Rheumatol; 36 (2): $97-100$.

9. Das $\mathbf{S}$ (2008): Hyaluronic acid in rheumatoid arthritis: some facts. J. Chin Med. Assoc., 71(11): 601.

10. Kogan G, Soltés L, Stern $R$ and Gemeine $P$ (2007): Hyaluronic acid: a natural biopolymer with a broad range of biomedical and industrial applications. Biotechnol. Lett., 29(1): 17-25.

11. McHutchison JG, Blatt LM and Medina MD (2000): Measurement of serum hyaluronic acid in patients with chronic hepatitis $\mathrm{C}$ and its relationship to liver histology. J. Gastroentrol. Hepatol., 15: 945951.

12. Wilkinson CR, Bower $L M$ and Warren C (1996): The relation between hyaluronidase activity and hyaluronic acid concentration in sera from normal controls and from patients with disseminated neoplasm. Clin. Chim. Acta 256: 165-73.

13. Faber J, Horslev-Petersen $K$, Perrild $H$ and Lorenzen I (1990): Different effects of thyroid disease on serum levels of procollagen III N-peptide and hyaluronic acid. J Clin. Endocrinol. Metab., 71: 1016-21.
14. Ozasa H, Chichibu K, Tanaka $Y$, Kondo $T$, Kitajima $K$ and Ota K (1992): Relationship between plasma levels of hyaluronic acid and amyloidassociated osteoarthropathy in chronic hemodialysis patients. Nephron 61: 187-91.

15. Elliott AL, Kraus VB, Luta G, Stabler T, Renner JB, Woodard J, Dragomir AD, Helmick CG, Hochberg MC and Jordan JM (2005): Serum hyaluronan levels and radiographic knee and hip osteoarthritis in African Americans and Caucasians in the Johnston Country Osteoarthritis Project. Arthritis and rheumatism 52 (1): 105-111.

16. Lundin A, Engstrom-Laurent A, Hallgren $R$ and Michaelsson G (1985): Circulating hyaluronate in psoriasis. Br. J. Dermatol., 112: 663-71.

17. Arnett FC, Edworthy SM, Bloch DA, McShane DJ, Fries JF, Cooper NS, et al. (1988): The American Rheumatism Association 1987 revised criteria for the classification of rheumatoid arthritis. Arthritis Rheum., 31: 315-24.

18. Larsen A, Dale Kand Eek $M$. (1977): Radiographic evaluation of rheumatoid arthritis and related conditions by standard reference films. Acta. Radiol. Diagn., 18(4): 481-491.

19. Prevoo ML, van 't Hof MA, Kuper HH, van Leeuwen MA, van de Putte $L B$ and van Riel PL (1995): Modified disease activity scores that include twenty-eight-joint counts: development and validation in a 
prospective longitudinal study of patients with rheumatoid arthritis. Arthritis Rheum., 38: 44-8.

20. Wollheim FA, Pettersson $H$, Saxne $T$ and Sjöblom KG. (1988): Radiographic assessment in relation to clinical and biochemical variables in rheumatoid arthritis. Scand. J. Rheumatol.,17(6): 445-453.

21. Plevris JN, Haydon GH and Simpson KJ (2000): Serum hyaluronan-a non-invasive test for diagnosing liver cirrhosis. Eur. J. Gastro \& Hepatology 12: 1121-1127.

22. Saxne $T$ and Heinegard $D$ (1992): Cartilage oligomeric matrix protein: A novel marker of cartilage turnover detectable in synovial fluid and blood. Br. J. Rheumatol., 31: 583-591.

23. Roberts, W; Moulton, L; Law, T; Farrow G; Cooper, $S$ and Rifai, N (2001): Evaluation of nine automated high sensitive $\mathrm{C}$ reactive protein methods: Implications for clinical and epidemiological applications. Partz. Clin. Chem., 47: 418 - 425.

24. Wolfe F (1991): Arthritis and rheumatism. 34: 951-960.

25. Zweig $\mathrm{MH}$ and Campbell G (1993): Receiver-operating characteristic (ROC) plots: a fundamental evaluation tool in clinical medicine. Clin. Chem., 39: 561-77.

26. Panayi GS. (1992): The immunopathogenesis of rheumatoid arthritis. Rheumatology Review 1: 63-74.

27. Bengt M, Dennis C, Mauro A, Mirela I, Lawrence R, Robin P, Dick $H$ and Tore $S$ (1995):
Cartilage and bone metabolism in rheumatoid arthritis: Differences between rapid and slow progression of disease identified by serum markers of cartilage metabolism. J.Clin. Invest., 95 (3): 1071-1077.

28. Majeed $M$, McQueen F, Yeoman $S$ and Mclean $L$ (2004): Relationship between serum hyaluronic acid level and disease activity in early rheumatoid arthritis. Ann. Rheum. Dis., 63: 1166-1168.

29. Young-Min S, Cawston $T$, Marshall N, Coady D, Christgau S, Saxne T, Robins S and Griffiths I (2007): Biomarkers predict radiographic progression in early rheumatoid arthritis and perform well compared with traditional markers. Arthritis Rheum., 56 (10): 3236-47.

30. Santos ME, Kondo T, Wieczorek A, Lopez LR (1994): Increased serum hyaluronic acid levels in rheumatoid arthritis. Arthritis Rheum., 37: 247-252.

31. Chubinskaya S, Frank BS, Michalska M, Kumar B, Merrihew CA, Thonar EJ, Lenz ME, Otten L, Rueger DC and Block JA (2006): Osteogenic protein 1 in synovial fluid from patients with rheumatoid arthritis or osteoarthritis: relationship with disease and levels of hyaluronan and antigenic keratan sulfate. Arthritis Res. Ther., 8 (3): 73.

32. Pothacharoen

P, Teekachunhatean

S, Louthrenoo W, Yingsung $\mathbf{W}$, Ong-Chai S, Hardingham T 
and Kongtawelert $P$ (2006):

Raised chondroitin sulfate epitopes and hyaluronan in serum from rheumatoid arthritis and osteoarthritis patients. Osteoarthritis Cartilage 14(3): 299-301.

33. Poole AR

(1994):

Immunochemical markers of joint inflammation, skeletal damage and repair: where are we now? Ann. Rheum. Dis., 53: 3-5.

34. Galeotti L, Adrian K, Berg S, Tarkowski $A$ and Bokarewa $M$ (2008): Circulating survivin indicates severe course of juvenile idiopathic arthritis. Clin. Exp. Rheumatol., 26 (2): 373-8.

35. Skoumal $M$, Kolarz $G$ and Klingler A (2003): Serum levels of cartilage oligomeric matrix protein. A predicting factor and a valuable parameter for disease management in rheumatoid arthritis. Scand. J. Rheumatol., 32 (3): 156-61.

36. Emlen W, Niebur J, Flanders $\mathbf{G}$ and Rutledge $J$ (1996): Measurement of serum hyaluronic acid in patients with rheumatoid arthritis: correlation with disease activity. J. Rheumatol., 23 (6): 974-8.

37. Wislowska $M$ and Jablonska $B$ (2005): Serum cartilage oligomeric matrix protein (COMP) in rheumatoid arthritis and knee osteoarthritis. Clin. Rheumatol., 24 (3): 278-84.

38. Marti $C$, Neidhart $M$, Gerber T, Hauser N, Michel BA and Hauselmann HJ (1999): Cartilage oligomeric matrix protein (COMP): the role of a non-collagen cartilage matrix protein as a marker of disease activity and joint destruction in patients with rheumatoid arthritis and osteoarthritis. Z. Rheumatol., 58 (2): 79-87.

39. De Jong $Z$, Munneke M, Vilim V, Zwinderman AH, Kroon HM, Ronday HK, Lems WF, Dijkmans BA, Breedveld FC, Vliet Vlieland TP, Hazes JM and Degroot J (2008): Value of serum cartilage oligomeric matrix protein as a prognostic marker of large-joint damage in rheumatoid arthritis--data from the RAPIT study. Rheumatology (Oxford) 47 (6): 868-71.

40. Lindqvist E, Eberhardt K, Bendtzen $\mathrm{K}$, Heinegard D, Saxne T(2005): Prognostic laboratory markers of joint damage in rheumatoid arthritis. Ann. Rheum. Dis., 64: 196-201.

41. Momohara S, Yamanaka $H$, Holledge MM, Mizumura T, Ikari K, Okada N, Kamatani N and Tomatsu $T$ (2004): Cartilage oligomeric matrix protein in serum and synovial fluid of rheumatoid arthritis: potential use as a marker for joint cartilage damage. Mod. Rheumatol., 14(5): 356-60.

42. Söderlin MK, Kastbom A, Kautiainen H, Leirisalo-Repo M, Strandberg $G$ and Skogh T (2004): Antibodies against cyclic citrullinated peptide (CCP) and levels of cartilage oligomeric matrix protein (COMP) in very early arthritis: relation to diagnosis and disease activity. Scand. J. Rheumatol., 33 (3): 185-8. 
43. Fujikawa K, Kawakami A, Tamai M, Uetani M, Takao S, Arima K, Iwamoto N, Aramaki T and Eguchi K (2009): High serum cartilage oligomeric matrix protein determines the subset of patients with early-stage rheumatoid arthritis with high serum C-reactive protein, matrix metalloproteinase-3, and MRI- proven bone erosion. J.Rheumatol., 36 (6): 1126-9.

44. Skoumal M, Haberhauer G, Feyertag J, Kittl EM, Bauer K and Dunky A (2006): Serum levels of cartilage oligomeric matrix protein (COMP): A rapid decrease in patients with active rheumatoid arthritis undergoing intravenous steroid treatment. Rheumatol. Int., 26 (11): 1001-4.

\section{حامض الهيالورنيك و بروتين النسيج الغضروفى كمؤشرات لتطور مرض الفوض الروماتويد المفصلى الفطروف}

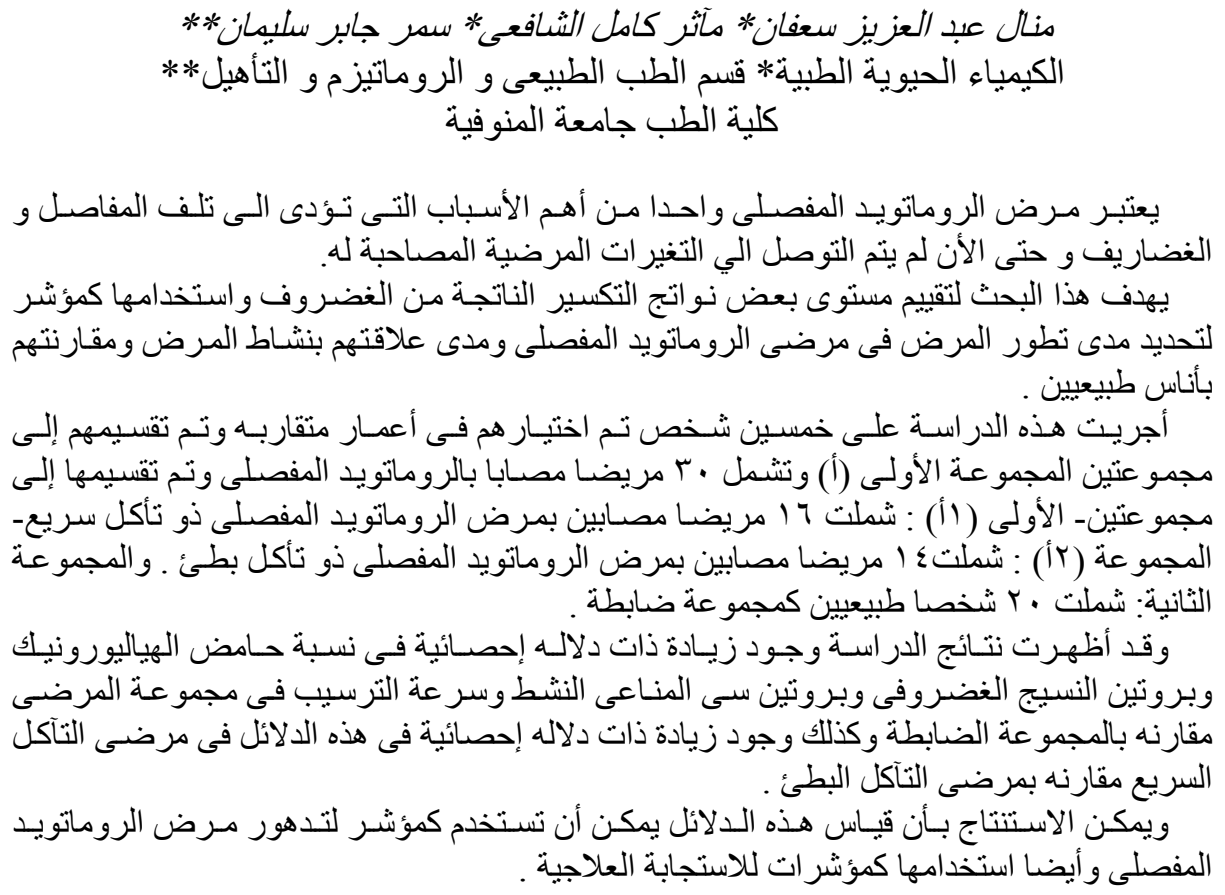

